\title{
What are Cycads?
}

\section{Andrew P Vovides*}

Instituto de Ecología, Mexico

*Corresponding author: Andrew P Vovides, Instituto de Ecología, Mexico

Submission: 眥January 26, 2019; Published: 眥 February 5, 2019

\section{Mini Review}

Cycads are amongst the most ancient group of living seed plants known and have a fossil history that dates to more than 200 million years [1]. They were at their height during the times of the dinosaurs, forming part of the world vegetation during the Mesozoic era (160million years ago). They superficially resemble palms or even ferns though totally unrelated since they do not bear flowers but cones. They are gymnosperms that include conifers, and cycads occur in separate sexes there being female and male plants. Cycads had a much wider distribution during the historic past with fossils found in Alaska, Russia, Britain and the USA. During the Jurassic period (mid Mesozoic) commonly known as the "age of cycads and dinosaurs" the cycads formed an important part of the world vegetation and were an important food source to many plant eating dinosaurs (Figure 1). Cycads have survived the dinosaurs and today they only occur within the tropics and subtropics of the globe and are considered threatened or endangered. In the mid1980s about 130 cycad species were known worldwide, at present there are 355 species worldwide and about 60 are known in Mexico placing the country 2nd worldwide for cycad diversity, Australia occupies first place with about 78 species [2,3]. All this is due to renewed interest in the group with more botanical explorations made into remote regions. Discoveries of new cycad species are still being made worldwide, and the figure is growing as further research is being done.

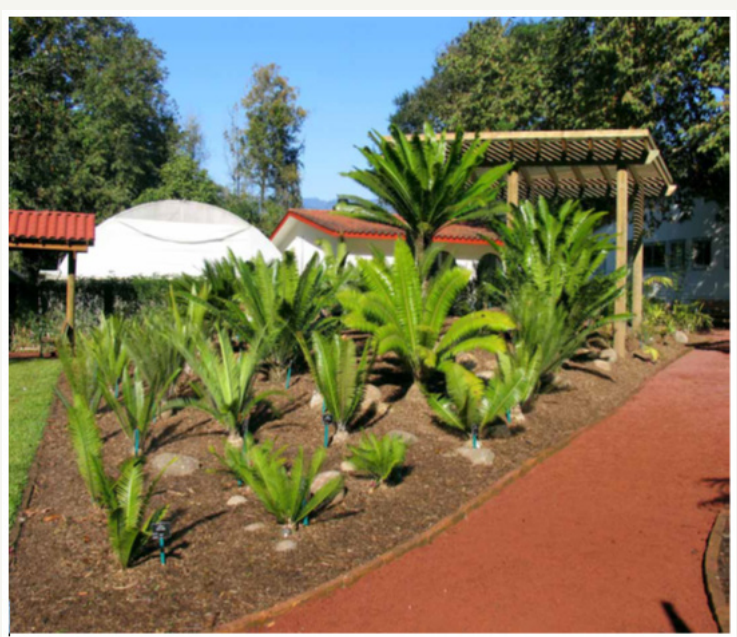

Figure 1: The Mexican national cycad collection at the Clavijero Botanic Garden.
Looking at cycads from a distance the un-experienced would be excused for calling them palms, since these plants bear long feather-like leaves crowning the apex of a relatively short thick stem or trunk. The trunks may be solitary or branched depending on age and species. Infact it would be more correct to say that palms are cycad-like since the cycad families are of far greater age than the palms that are classified as flowering plants. When you have a closer look at cycad cones you will find a certain resemblance to those of the conifers; the seed-bearing cone bears naked seeds, hence the term gymnosperm in that the seed lacks the ovary wall that forms the true fruit of a flowering plant such as a plum (Figure 2). All cycads bear two ovules per fertile cone scale, as do pines except old world Asian genus Cycas, these do not bear true female cones as such, but open or loose cones whose fertile scales bear up to 7 or more ovules on the scale margins. The major difference between cycad cones and pinecones is that the cycad cones are called simple cones in that they do not have a bract scale associated with the fertile cone scales whereas the pine cones are compound, there is a single bract scale associated with each fertile scale [4]. The female scale apex of the popular houseplant Cycas revoluta resembles that of a fossil (Crossozamia) 280 million years of age from the Permian of southern China that indicates a deep ancestry [5]. The internal structure of the modern cycad seed is not unlike that of certain Permian fossil seeds known to belong to an extinct group of plants called seed ferns, likewise the stem anatomy of the living cycads has changed little from that of their Permian ancestors.

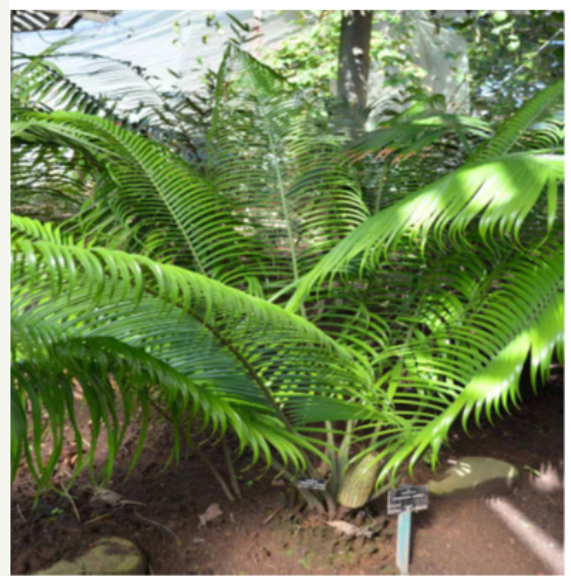

Figure 2: Rare and endemic Mexican cycad Ceratozamia vovidesii from Chiapas at the national cycad collection. 
Female cones of cycads range greatly in size depending on species and can vary from just a few grams to over 20 kilos. The pollen cones are much more slender and lighter, looking very much like sweet corn. The fertile scales bear the pollen sacs on their undersides which vary in number to just a few in some small rain forest zamias to well over a hundred in the larger cycad species. The pollen cone is home to the beetle pollinators where they feed on the starch rich tissues, breed and over-winter as larvae [6]. During the pollination season the beetles are attracted to the cones by volatiles emitted by the receptive cones, they emerge from the male cones covered in pollen and are attracted to the female cones where they enter and deposit pollen on the ovules but are quickly expelled [7]. Another very primitive feature of cycads as seed plants and only shared by the living Ginkgo tree is that they have motile sperms a feature shared by the ferns [1].

Cycads are enlisted as rare, threatened or endangered by the IUCN Red List and are protected internationally by CITES (the Convention of International Trade of Endangered Species of Fauna and Flora). They are appreciated mainly as ornamental plants for landscaping and collections, and they are quickly disappearing from their natural habitats through habitat loss as well as illegal international trade, since they command high prices for large specimens on the black market [8]. They are also important from an ethnobotanical point of view since many native human cultures use them as a food source or for religious festivities [9-11].

From a Biomedical viewpoint they are an important group since their toxins are unique in the plant kingdom some of which are the most powerful naturally occurring carcinogens and the neurotoxin (BMAA) that is implicated with lateral amyotrophic sclerosis in humans and is now disputed $[12,13]$.

Though cycads have a long ancestry, the species living today are recently evolved from an ancestral stock, whereas the species may be modern, but the genera and families are not [14] which makes them more fascinating since some are still in active speciation.

\section{References}

1. Norstog KJ, Nicholls TJ (1997) The biology of the cycads. Cornell University Press, Ithaca, New York, USA.

2. Calonje M, Stevenson DW, Osborne R (2013-2019) The world list of cycads, online edition.

3. Vovides AP (2000) México: segundo lugar mundial en diversidad de cícadas. Biodiversitas 6: 6-10.

4. Foster AS, Gifford EM (1974) Comparative morphology of vascular plants. Freeman, San Francisco, California, USA.

5. Gao Z,Thomas BA (1989) A review of fossil cycad mega sporophylls, with new evidence of Crosszamia Pomel and its associated leaves from the lower Permian of Taiyuan, China. Review of Paleobotany and Palynology 60: 205-223.

6. Norstog KJ, Fawcett PKS (1989) Insect-cycad symbiosis and its relation to the pollination of Zamia furfuracea (Zamiaceae) by Rhopalotria mollis (Curculionidae). American Journal of Botany 76: 1380-94.

7. Terry I, Walter GH, Moore C, Roemer R, Hull C, (2007) Odor-mediated push-pull pollination in cycads. Science 318(Oct): 70.

8. Donaldson JS, Dehgan B, Vovides AP, Tang W (2003) Cycads in trade and sustainable use of cycad populations. Cycads Status Survey and Consevation. Action Plan, In: J Donaldson (Eds.). Gland, IUCN: 39-47.

9. Bonta M, Pinot OF, Graham D, Haynes J, Sandoval G (2006) Ethnobotany and conservation of tiusinte (Dioon mejiae Standl. \& L.O. Williams, Zamiaceae) in northeastern Honduras. Journal of Ethnobiology 26: 228257.

10. Bonta M, Pulido Silva MT, Diego VT, Vite RA, Vovides AP et al. (2019) Ethnobotany of Mexican and northern Central American cycads (Zamiaceae). Journal of Ethnobiology and Ethnomedicine On-Line

11. Pérez FMA, Vovides AP (2006) The ceremonial use of the threatened "Espadaña" cycad (Dioon merolae, Zamiaceae) by a community of the central depression of Chiapas Mexico. Boletín de la Sociedad Botánica de México 78: 107-113.

12. Whiting MG (1963) Toxicity of cycads. Economic Botany. 17: 270-302.

13. Vovides AP, Norstog KJ, Fawcett PKS, Duncan MW, Nash RJ et al. (1993) Histological changes during maturation in male and female cones of the cycad Zamia furfuracea and their significance in relation to pollination biology. Botanical Journal of the Linnean Society 111: 241-252.

14. Nagalingum NS, Marshall CR, Quental TB, Rai HS, Little DP, et al. (2011) Recent synchronous radiation of a living fossil. Science 334: 796-799.
Creative Commons Attribution 4.0 International License

For possible submissions Click Here

\section{Submit Article}

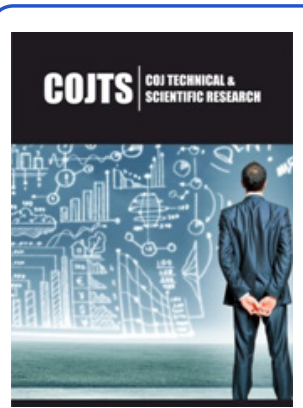

COJ Technical \& Scientific Research

\section{Benefits of Publishing with us}

- High-level peer review and editorial services

- Freely accessible online immediately upon publication

- Authors retain the copyright to their work

- Licensing it under a Creative Commons license

- Visibility through different online platforms 